\title{
An Integrated Corporate Governance Framework and Financial Performance in South African Listed Corporations
}

\author{
Collins G. Ntim* \\ Accounting and Finance, Business School \\ University of Glasgow \\ UK
}

*Address for correspondence: Accounting and Finance, Business School, University of Glasgow, West Quadrangle, Main Building, University Avenue, Glasgow, G12 8QQ. Tel: +44 (0) 1413307677 . Fax: +44 (0) 141330 4442. E-mail: Collins.Ntim@glasgow.ac.uk or cgyakari@yahoo.com. 


\section{An Integrated Corporate Governance Framework and Financial Performance in South African Listed Corporations}

Abstract

This paper investigates the relationship between an integrated corporate governance (CG) index and financial performance using a sample of 169 South African (SA) listed corporations between 2002 and 2007. We find a statistically significant and positive association between a broad set of good CG practices and financial performance. In a series of sensitivity analyses, we find that our results are robust to endogeneity, different financial performance proxies, alternative CG weighting scheme and firm-level fixedeffects. We further distinctively examine the link between complying with SA context specific stakeholder CG provisions and financial performance. In line with political cost

and resource dependence theories, our results reveal a statistically significant and positive nexus between compliance with stakeholder CG provisions and financial performance.

JEL classification: G30, G34, G38

Keywords: corporate governance, corporate financial performance, affirmative action and stakeholder provisions, King II and South Africa, endogeneity 


\section{INTRODUCTION}

The purpose of this paper is to investigate the association between a set of an integrated good corporate governance $(\mathrm{CG})$ practices and the financial performance of companies listed on the South African (SA) Stock Exchange (the JSE). Specifically, we examine whether better-governed SA public corporations generate higher financial performance, and whether compliance with SA context specific affirmative action and stakeholder CG provisions does impact on the financial performance of JSE listed companies. Theoretically, a reduction in agency costs associated with good governance may affect corporate financial performance (Davidson, 1995, 1998; Ntim et al., 2011b). First, good governance reduces monitoring and bonding costs, such as auditing (Jensen and Meckling, 1976; Ntim et al., 2011b). Second, good governance makes investors optimistic about future cash flows (Jensen, 1986; Ntim et al., 2011a). Investors bid-up share prices because with better governance, they are likely to receive a greater proportion of their firms' profits instead of being expropriated by mangers (La Porta et al., 2002; Beiner et al., 2006). Finally, and as equity values appreciate, the cost of outside capital and/or risk tend to fall (Black et al., 2006a; Chen et al., 2009), and thereby improving corporate performance.

Generally, recent evidence offers empirical support for the theory that good governance is priced by stock markets. Beiner et al. (2006), Black et al. (2006a), Cheung et al. (2007) and Henry (2008) report positive relationship between a broad set of CG ratings and firm financial performance for a sample of Swiss, Hong Kong, Korean and Australian listed corporations, respectively. Similarly, cross-country studies by Klapper and Love (2004), Durnev and Kim (2005) and Morey et al. (2009) show a positive association between a set of an integrated good CG practices and corporate financial performance.

A major issue of interest is that prior studies on the link between integrated CG indices and financial performance have been so far concentrated mainly on the developed and emerging stock markets of America, Asia-Pacific and Europe (Beiner et al. 2006, Black et al. 2006a and b; 
Cheung et al., 2007; and Henry, 2008). Within the African context, a number of previous studies have examined the effect of individual CG mechanisms on corporate performance (e.g., Kyereboah-Coleman and Biekpe, 2006; Kyereboah-Coleman et al., 2006; Kyereboah-Coleman, 2007; Sunday, 2008; Sanda et al., 2010; Ntim and Osei, 2011). By contrast, and largely due to data limitations, evidence on the effect of an integrated $\mathrm{CG}$ index on corporate performance in Africa is virtually non-existent (Okeahalam, 2004; Barako et al., 2006; Mangena and Chamisa, 2008; Ntim et al., 2011a). However, some African countries, and in particular, SA arguably offer an interesting research context, where the association between an integrated set of good CG ratings and corporate performance can be investigated.

On the one hand, and unlike most African countries, SA possesses a relatively sound financial and regulatory structure reminiscent of developed markets, such as UK and US. For example, and like the UK (see Mallin, 2006, pp.3 to 9 for a quick review of how CG has evolved in the UK), CG seems to be fluidly developing. As will be explained further below, a formal code of CG was first introduced in 1994 (King I), and revised in 2002 (King II). To achieve greater supervision and monitoring, rigorous insider trading law and listing rules have been introduced, and enforcement is being strengthened (Insider Trading Act 1998; JSE Listing Rules, 2007). Also, and in contrast to most African countries, SA has deep equity culture comparable with those of other emerging and developed economies (Deutsche Bank, 2002; Malherbe and Segal, 2003). For instance, market capitalisation to GDP ratio in 2007 for SA was 293\%, and this compares with $139 \%$ and $113 \%$ for the UK and US (WFE, 2011), respectively.

On the other hand, and as will be discussed further below, the SA corporate landscape depicts significant differences with the UK corporate environment. However, like most developing Commonwealth countries, CG principles have mainly been borrowed from the UK. This brings into question as to the applicability of some of these CG mechanisms to the SA 
corporate context. It also implies that the relationship between integrated CG ratings and corporate performance may be different from what has been reported for UK listed corporations.

For example, and as will be explained further in section 2, while the SA CG model is predominantly Anglo-American (shareholding), King II formally imposes substantial affirmative action and stakeholder demands (stakeholding) on listed corporations to comply with. This raises the crucial policy question of whether the current SA CG framework is sufficiently robust to effectively pursue the contrasting agenda of maximising shareholder returns and providing a meaningful protection of the interests of a larger stakeholder group (Kakabadse and KoracKakabadse, 2002; West, 2006, 2009). Similarly, as an emerging market, ownership of firms is relatively concentrated (Barr et al. 1995; Ntim, 2009). By contrast, UK corporations have relatively dispersed ownership structure. This implies that unlike the UK, the market for managerial and corporate control through which non-performing managers and companies are expected to be disciplined may not be effective in SA (Barr et al., 1995; Ntim et al., 2011a).

Also, while SA dominates African continental market capitalisation (over 70\%) (WFE, 2011), it is considerably smaller compared with the UK. Specifically, it has fewer numbers of listed corporations, lower liquidity, and smaller, but concentrated market capitalisation in relation to the UK (WFE, 2011). This implies that the impact of conventional UK-style CG mechanisms on the financial performance of SA listed companies may be different from UK listed corporations. Finally, and different from most African countries, SA is home to some of the world's largest multinationals, which attract substantial foreign direct investments, mainly from large UK and US institutional investors (Armstrong et al., 2006; Forbes, 2011). This means that unlike most African countries, any CG failures may have serious implications far beyond SA and Africa. We contend that the rich research context in terms of similarities and differences with the $\mathrm{UK}$, in addition to the dearth of prior studies serve as a strong motivation to examine the effect of an integrated CG index on corporate financial performance. 
This paper makes a number of contributions. First, using CG data collected from annual reports, we construct an integrated CG index for a sample of 169 SA listed corporations from 2002 to 2007. Our index consists of 50 CG provisions based on the 2002 King Code (King II) for SA corporations. Second, we provide evidence on the association between an integrated CG index and financial performance for SA listed corporations. This also extends the international evidence to SA corporate context. Finally, and distinct from prior studies, we offer evidence on how compliance with SA context specific affirmative action and stakeholder CG provisions affect the financial performance of SA listed corporations.

Our results show a statistically significant and positive association between our integrated CG index and corporate financial performance. This implies that SA listed corporations with better CG standards tend to be associated with higher financial performance. In a series of sensitivity analyses, we find that our evidence is robust to: (1) endogeneity; (2) market or accounting based financial performance proxies; (3) alternative CG index weighting scheme; and (4) firm-level fixed-effects. Also, and consistent with political cost and resource dependence theories, we find a statistically significant and positive association between compliance with SA context specific affirmative action and stakeholder $\mathrm{CG}$ provisions and financial performance.

The remainder of the paper is organised as follows. Section 2 provides an overview of the South African CG model. Section 3 reviews the prior literature on the link between integrated CG indices and financial performance. Section 4 describes the data and research methodology. Section 5 reports empirical results. Section 6 presents robustness, while section 7 concludes.

\section{THE SOUTH AFRICAN CORPORATE GOVERNANCE MODEL}

South Africa (SA) was the first developing country to introduce a corporate governance (CG) code in the form of the 1994 King Report (Mallin, 2006, 2007; Ntim et al., 2011a). The recommendations of the 1994 King Report (hereafter King I) were heavily informed by those of 
the UK's Cadbury Report of 1992 (Mangena and Chamisa, 2008; Ntim and Osei, 2011). For example, and in line with the Cadbury Report, King I adopted an Anglo-American style unitary board of directors, consisting of executive and non-executive directors (NEDs), who are primarily accountable to shareholders. Also, SA corporations were required to split the roles of chairman and CEO, set-up audit and remuneration committees with at least two non-executive directors as board members. Similar to the Cadbury Report, King I was appended to the JSE listing rules with a voluntary (comply or explain) compliance regime.

King I was reviewed in 2002 following important domestic (legislation, such as the Employment Equity Act, 1998) and international (new Codes, like the UK Combined Code, 1998) developments. A major distinguishing feature of the 2002 King Report (hereafter King II) from other Anglo-American CG Codes is that it adopted the 'inclusive' approach to CG (West, 2006, 2009). That is, while King II maintains and strengthens the Anglo-American (shareholding) features (like voluntary compliance regime, unitary board, and majority NEDs), substantial SA context specific affirmative action and stakeholder demands (stakeholding), aimed at addressing the lingering negative social and economic legacies of Apartheid are 'formally' superimposed on listed firms to comply with. They include employment equity (EE), black economic empowerment (BEE), environment and HIV/Aids.

This compels SA corporations to depict some of the key characteristics of both the 'shareholding' (Anglo-American) and 'stakeholding' (Continental European-Asian) models of CG. This makes the SA CG model a 'hybrid' or unique within the Anglo-American world (Mallin, 2006, 2007; Andreason, 2009). Critics of King II (Kakabadse and Korac-Kakabadse, 2002; Spisto, 2005), however, argue that it is inappropriate to explicitly superimpose affirmative action and stakeholder demands on a CG model that has a predominantly 'shareholding' orientation. We, therefore, seek to empirically examine the relationship between a broad set of CG index and corporate financial performance within such an interesting context. 


\section{PRIOR LITERATURE: AN INTEGRATED CG INDICES AND PERFORMANCE}

A number of papers have investigated the association between integrated CG indices and corporate financial performance. For example, Gompers et al. (2003), Cremers and Nair (2005), Chhaochharia and Grinstein (2007), and Bebchuk et al. (2009) have examined the nexus between broad composite CG indices and corporate performance for a sample of US corporations. The results of these studies generally suggest that better-governed US corporations tend to be associated with higher financial performance.

In the larger continental Europe, due to limited availability of sufficient CG data, very little research has been done that studies the relationship between a broad set of CG indices and corporate financial performance. Baur et al. (2004), Drobetz at al. (2004), Beiner et al. (2006) and Bauwhede (2009) are rare exceptions. Using a cross-sectional sample of 109 Swiss listed corporations, for example, Beiner et al. (2006) study the link between an integrated CG index based on 38 provisions from the 2002 Swiss Code of Best Practice and corporate financial performance, as measured by Tobin's Q. In line with the results of prior US and European studies (Gompers et al., 2003; Drobetz et al. 2004), they report a positive association between a broad set of good CG ratings and corporate financial performance.

Other studies have been conducted in the established emerging markets of America, AsiaPacific and Europe. For example, Black (2001), Baek et al. (2004), Black et al. (2006a and b), Black and Khanna (2007), Cheung et al. (2007), and Garay and González (2008) have investigated the link between a broad composite CG index and financial performance, using a sample of Russian, South Korean, Indian, Hong Kong and Venezuelan listed corporations, respectively. The results of these studies also offer empirical support to the positive nexus between integrated CG indices and corporate performance reported for developed markets. 
A conspicuous gap within the extant literature is the dearth of evidence regarding African stock markets (Okeahalam, 2004; Barako et al., 2006; Mangena and Chamisa, 2008; Ntim et al., 2011a $)^{2}$. However, and as has already been explained, some African countries, such as SA arguably offer interesting research context. The only evidence regarding African stock markets are cross-country studies by Klapper and Love (2004), Durnev and Kim (2005), and Morey et al. (2009). Klapper and Love (2004) and Durnev and Kim (2005), for instance, have used Credit Lyonnais Securities Asia's (CLSA) 2000 analysts' CG ratings to examine the association between a broad set of CG ratings and corporate performance in a sample of emerging markets that include SA. The results of these studies indicate that, on average, better-governed corporations tend to be associated with higher corporate financial performance.

However, these cross-country studies appear to suffer from a number of problems. First, they make use of analysts' CG ratings. A major problem with analysts' CG rankings is that they are based purely on analysts' perceptions of CG quality rather than on a direct examination of company annual reports (Beattie et al., 2004). Their findings may be considered to be of limited evidential value. Crucially, prior research suggests that analysts' CG ratings tend to be biased towards large corporations (Botosan, 1997; Ntim, 2009). The CLSA (2000) CG rankings that has mainly been used by prior studies, for example, includes only 9 of the largest SA listed corporations. Arguably, this limits the generalisation of their findings for SA listed corporations.

Second, the extant literature suggests that CG structures and systems vary across different countries (West, 2006, 2009). However, analysts' CG rankings are standardised such that they are unable to reflect institutional, cultural, and contextual differences in CG structures across individual countries and systems. This implies that they are unable to assess how compliance

\footnotetext{
${ }^{2}$ To the best of our knowledge, the only exception is Ntim et al. (2011b), which investigates the relative value relevance of shareholder versus stakeholder CG disclosures for SA listed corporations. Their results suggest that investors value shareholder related CG disclosures more highly than their stakeholder counterparts. This paper seeks to extend Ntim et al.'s study to focus on the direct links between an integrated CG index and financial performance.
} 
with SA context specific affirmative action and stakeholder CG issues impact on the financial performance of SA listed corporations. Finally, despite increasing concerns that the presence of endogenous problems can confound research findings (Bhagat and Bolton, 2008), with the exception of Durnev and Kim (2005), prior cross-country studies that include SA do not explicitly address potential problems that may be caused by the existence of an endogenous relationship between integrated $\mathrm{CG}$ indices and corporate performance. This also brings into doubt the reliability of the results of these prior cross-country studies that include SA.

The current study on SA attempts to overcome these limitations in prior studies in several ways. First, we use the entire useable sample of 169 SA listed corporations over the 2002-2007 period. Distinct from past studies, this allows us to capture the effects of both cross-sectional and time series changes in CG index on corporate performance, as well as improve the generalisation of the results. Second, we construct SA CG index (CGI) based on the CG provisions of King II. Unlike subjective analysts' rankings, it has the advantage of ensuring that unique SA contextual CG provisions, such as employment equity and HIV/Aids are incorporated into the methodology. Finally, to improve the reliability of the results, problems that may be posed by the presence of endogeneities, including firm-level fixed-effects are explicitly addressed.

\section{DATA AND RESEARCH METHODOLOGY}

\subsection{Data: sample selection, sources, and description}

In examining the association between our integrated CG index and corporate financial performance, we target all $291^{3}$ non-financial corporations listed on the JSE as at 31/12/2007. We use CG and financial performance data to investigate the link between our broad set of CG ratings and corporate performance. All the CG variables were manually extracted from the annual

\footnotetext{
${ }^{3}$ For regulatory and capital structure reasons, as well as following prior studies (Yermack, 1996; Guest, 2009), financial and utilities industries with 111 firms were excluded. This leaves us with 291 corporations from 8 industries to be sampled. The industrial breakdown is as follows: basic materials with 67 firms; consumer goods with 36 firms; consumer services with 62 firms; health care with 7 firms; industrials with 81 firms; oil \& gas with 3; telecommunications with 4 firms; and technology with 31 firms.
} 
reports of the sampled companies. The annual reports were mainly obtained from the Perfect Information Database (PID) in electronic format. Since we were interested in examining the relationship between our integrated set of $\mathrm{CG}$ practices and corporate financial performance over time, we focused on companies with the full $\mathrm{CG}$ and financial data required over the whole sample period (i.e., 2002 to 2007) ${ }^{4}$ available in the PID and DataStream, respectively. We obtained the full data required for a total of $169^{5}$ out of the 291 corporations over the sample period for our regression analysis.

\subsection{Research methodology: definition of variables and model specification}

The constructed broad SA CG index $(C G I)$ is the main independent variable used in investigating the association between $\mathrm{CG}$ and corporate performance. The $C G I$ is an aggregation of 50 comprehensive set CG provisions contained in King II. The CGI is constructed based on the 5 broad sections of King II covering: (1) boards, directors and ownership; (2) accounting and auditing; (3) risk management, internal audit and control; (4) integrated sustainability reporting; and (5) compliance and enforcement. All companies listed on the JSE are required to comply with the $\mathrm{CG}$ provisions or give reasons for non-compliance. The Appendix contains the 5 broad sections and the various variables that make-up the $C G I$.

Our $C G I$ is distinct from those of prior research. First, unlike previous studies that focus on specific aspects of CG in isolation, for instance, shareholder rights (Gompers et al., 2003; Cremers and Nair, 2005), and board size (Yermack, 1996; Guest, 2009), but similar to Beiner et al. (2006), it covers all aspects of CG. This allows for the existence of potential interdependences among alternative CG mechanisms. Second, in line with prior studies (Black et al., 2006a and b),

\footnotetext{
${ }^{4}$ The sample begins from 2002 because data coverage in the PID and DataStream for our sample is limited until that year, and also it is the year King II became operational. It ends in 2007 because it is the most recent year for which data is available.

${ }^{5}$ The industrial breakdown of our final sample is as follows: basic materials and 0il \& gas with 34 firms; consumer goods with 24 firms; consumer services and health care with 38 firms; industrials with 51 firms; and technology \& telecommunications with 22 firms.
} 
our CGI covers conventional CG issues, such as board and ownership, but distinct from past studies (Klapper and Love, 2004; Morey et al. 2009), it covers SA context specific affirmative action and stakeholder CG provisions (a sub-index defined as SCGI that contains 9 provisions of the $C G I$ will be formed, see section 5 of the Appendix), like employment equity and HIV/Aids.

The construction of the CGI is simple - we award a value of ' 1 ' if any of the 50 CG provisions of King II covering the 5 sections in the Appendix is disclosed in an annual report or ' 0 ' otherwise. With this scoring scheme, a company's total score in a particular firm year can vary between zero (0\%) to fifty $(100 \%)$, with better-governed firms having higher index levels.

Our measure of corporate financial performance is the widely used Tobin's $\mathrm{Q}(Q)$, but to check the robustness of our results, we use return on assets (ROA) and total share returns (TSR), as alternative accounting and market based performance measures, respectively. To minimise potential omitted variables bias, we include a number of control variables. First, corporations with higher investment opportunities tend to grow relatively faster (Durnev and Kim, 2005). Theoretically, faster growing corporations may generate higher performance (Klapper and Love, 2004). Also, corporations with greater growth opportunities will need to raise external capital, and may need to adopt better CG to attract capital (Beiner et al., 2006). Following prior literature (Henry, 2008), a positive $Q$-growth opportunities (GROWTH) link is hypothesised.

Second, corporations with higher investment in innovation and technology may gain competitive advantage by launching new products and services (Brown et al., 2009). This may help them to receive premium prices and generate higher $Q$ (Jermias, 2007). By contrast, innovation is capital intensive (Weir et al., 2002), and as such may impact negatively on current $Q$. In line with past research (Black et al., 2006b), capital expenditure (CAPEX) is predicted to correlate significantly with $Q$, without specifying the direction of the coefficient. Third, from an agency perspective, Jensen (1986) suggests that higher levels of gearing can increase performance by reducing agency conflicts associated with having 'excess cash flows' by 
opportunistic managers. In contrast, the costs of financial distress that are usually associated with higher levels of gearing may inhibit a company's ability to pursue profitable investment opportunities (Jensen, 1986). Similar to past CG research (Bhagat and Bolton, 2008), gearing is controlled for. However, given the mixed evidence, gearing (GEAR) is hypothesised to either correlate positively or negatively with $Q$.

Fourth, due to greater political costs, stronger financial strength and greater agency problems, larger corporations are likely to maintain better $\mathrm{CG}$ regime, and may receive higher $Q$ (Beiner et al., 2006). By contrast, smaller firms tend to have better growth opportunities (Klapper and Love (2004). This means smaller firms may have to maintain better CG regimes to be able to attract external capital and receive higher $Q$. Given the mixed literature, we hypothesise a positive or negative firm size (LNTA)- $Q$ association. Fifth, firms that cross-list on foreign stock markets tend to have better CG structures, as they can be subjected to additional CG rules, and may generate higher $Q$ (Black et al., 2006a). Thus, a positive cross-listing (CROSLIST)- $Q$ relationship is hypothesised.

Sixth, auditor independence and audit quality are positively associated with audit firm size (DeAngelo, 1981). This implies that corporations audited by large and reputable audit firms may generate higher $Q$. Hence, we predict a positive audit firm size (BIG4)- $Q$ nexus. Finally, in line with prior studies (Beiner et al., 2006; Henry, 2008), we predict that $Q$ will differ across different industries and financial years. As such, we introduce 5 dummies for the 5 remaining industries: basic materials and oil \& gas (BMAT); consumer goods (CGOODS); consumer services and health care (CSERVICES); industrials (INDUST); and technology \& telecommunications (TECHN); and year dummies for the financial years 2002 to 2007 inclusive. Following prior research, and assuming that all relations are linear, our main OLS regression equation to be estimated is: 


$$
Q_{i t}=\alpha_{0}+\beta_{1} C G I_{i t-1}+\sum_{i=1}^{n} \beta_{i} \text { CONTROLS }_{i t-1}+\varepsilon_{i t-1}
$$

where: $Q$ refers to Tobin's Q; CGI is the SA CG index; and CONTROLS refers to the control variables for growth $(G R O W T H)$, capital expenditure $(C A P E X)$, gearing $(G E A R)$, firm size (LNTA), cross-listing (CROSLIST), audit firm size (BIG4), and industry (INDUST) and year (YD) dummies.

The following section presents and discusses the univariate and multivariate results.

\section{EMPIRICAL RESULTS}

\subsection{Empirical results: descriptive statistics and univariate regression analysis}

Table 1 reports descriptive statistics of all variables included in our regression analysis. It shows that our $Q$ ranges from a minimum of .15 to a maximum of 7.98 with an average of 1.55. This indicates wide variation in the financial performance of our sampled corporations. Our alternative financial performance proxies, namely TSR and ROA, as well as the $C G I$ and the $S C G I$ also show wide standard deviations. For example, the CGI suggests that the scores range from a minimum of $6 \%$ (i.e., 3 out of 50) to a maximum of $98 \%$ (i.e., 49 out of 50) with the average corporation complying with $61 \%$ of the $50 \mathrm{CG}$ provisions analysed. This suggests that a high degree of heterogeneity exists when it comes to the importance SA listed corporations attach to internal CG structures.

\section{Insert Table 1 about here}

Table 1 also indicates that, on average, compliance with the SCGI (which contains 9 SA context specific affirmative action and stakeholder CG provisions) are higher than the CGI. For example, the median corporation in our sample complied with $78 \%$ of the SCGI compared with

\footnotetext{
It takes time for good CG practices to be reflected in corporate financial performance (Weir et al., 2002; Ntim, 2009; Ntim et al., 2011b). Therefore, to avoid endogenous association between $\mathrm{CG}$ and corporate performance, we introduce a one year lag between $\mathrm{CG}$ and corporate financial performance such that a corporation's financial performance in any year $\left(Q_{t}\right)$ depends on the previous year's corporate governance $\left(\mathrm{CG}_{\mathrm{t}-1}\right)$ structure, similar to Weir et al. (2002) and Ntim and Osei (2011).
} 
$64 \%$ for the CGI. As will be discussed further, this development may be explained by political cost and resource independence theories. The control variables all have wide spreads. Generally, and unlike prior studies, the large standard deviations observed imply that the CG provisions and the sampled firms have been adequately selected to achieve sufficient variation. This reduces the possibilities of sample selection bias that have arguably plagued much of the prior cross-country studies whose samples include SA (Durnev and Kim, 2005; Morey et al., 2009).

We initially use OLS regression technique to test all our hypotheses. As a result, OLS assumptions of multicollinearity, autocorrelation, normality, homoscedasticity, and linearity are tested. The multicollinearity assumption is tested by conducting Pearson parametric and Spearman non-parametric correlation analyses among the variables. The results, which for brevity not reported, but available upon request, indicated that no serious non-normality and multicollinearity problems remain. In addition, we examined scatter, $P-P$ and $Q-Q$ plots, studentised residuals, Cook's distances and Durbin-Watson statistics. They also indicated no serious violation of the OLS assumptions of homoscedasticity, linearity, normality and autocorrelation, respectively.

\subsection{Empirical results: OLS (multivariate) regression analysis}

Table 2 reports OLS regression results of $Q$ on the CGI. Column 3 of Table 2 first presents the results of a simple regression of $Q$ on the $C G I$ only, whilst columns 4 to 8 contain the results of a regression of $Q$ on the $C G I$ and the control variables for the pooled sample in addition to a regression for each firm-year, respectively. As hypothesised, Column 3 of Table 2 shows that the CGI is positive (.006) and statistically significant. However, the significant coefficient on the constant term in column 3 of Table 2 seems to suggest that there may be omitted variables bias. Therefore, to control for potential omitted variables bias, the control variables are added to the regressions in columns 4 to 8 of Table 2. 
Insert Table 2 about here

Consistent with our prediction, the coefficient on the $C G I$ remains significant and positive over the entire sample period. This implies that investors reward SA listed corporations that show higher standards of CG with higher financial performance. Specifically, the results can be interpreted as a one standard deviation improvement in the average corporation's $C G I$ score from $61 \%$ to $80 \%$, can be expected to be associated with an increase in its average $Q$ by about $11 \%$ (19 $\mathrm{x} .006$ ) from 1.55 to 1.72 , ceteris paribus. Our results generally offer support to those of prior studies (Beiner et al., 2006; Henry, 2008), but specifically to those of past cross-country studies whose samples include SA (Klapper and Love, 2004; Durnev and Kim, 2005; Morey et al., 2009).

The coefficients on the control variables in the lower part of Columns 4 to 8 of Table 2 generally show the predicted signs. For example, and as hypothesised CROSLIST and GROWTH are positive and significantly associated with $Q$, while the coefficient on LNTA is negative and significantly related to $Q$ over the entire sample period. In line with the results of Henry (2008), the coefficient on the year dummies are significant, indicating that $Q$ differs over time, but the insignificant coefficients on the industry dummies except the consumer services companies do not support the results of Beiner et al. (2006). Finally, the F-values in Table 2 always reject the null hypothesis that the coefficients on the $C G I$ and control variables are equal to zero. The adjusted $R^{2}$ indicates that the $C G I$ can explain at least $6 \%$ to $41 \%$ of the variations in the sampled firms' $Q$ with or without the control variables.

As has been explained above, the uniqueness of our $C G I$ is that it incorporates 9 SA context specific affirmative action and stakeholder CG provisions (see section 5 of Appendix). These issues are of great importance within the SA corporate context. There is an on-going policy debate as to whether given the voluntary CG regime, SA listed corporations will voluntarily comply with these CG provisions (Spisto, 2005; West, 2009). However, there are mixed theoretical positions regarding the impact that compliance with stakeholder CG provisions will 
have on corporate financial performance. Stakeholder theorists (Kakabadse and KoracKakabadse, 2002; LSE, 2007) suggest that compliance with stakeholder CG provisions imposes additional financial costs on listed corporations.

In contrast, political cost (Watts and Zimmerman, 1978) and resources dependence (Pfeffer, 1973) theories indicate that compliance with stakeholder CG provisions does not only help in reducing political costs (such as taxation, regulation and nationalisation), but also offer greater access to resources (like tax holidays and profitable government contracts). To investigate the impact of complying with stakeholder CG provisions on corporate financial performance, we form a sub-index defined as SCGI containing 9 SA affirmative action and stakeholder CG issues. We hypothesise a significant association between the $S C G I$ and $Q$, but given the mixed literature, we do not specify the direction of the coefficient.

Table 3 contains OLS regression results of $Q$ on the SCGI. Column 3 of Table 3 first reports the results of a simple regression of $Q$ on the $S C G I$ alone, whereas columns 4 to 8 present the results of a regression of $Q$ on the SCGI and the control variables for the full sample in addition to a regression for each firm-year, respectively. Column 3 of Table 3 shows that the coefficient on the SCGI is positive (.002) and statistically significant. The coefficient on the constant term in column 3 of Table 3 is, however, significant, which implies that there may be omitted variables bias. As a result, to test that whether the positive relationship between the SCGI and $Q$ is spuriously caused by some omitted variables, the control variables are added to the regressions in columns 4 to 8 of Table 3 .

\section{Insert Table 3 about here}

The coefficient on the SCGI remains significant and positive over the entire sample period. This implies that, on average, corporations that comply better with the SCGI tend to be associated with higher financial performance. The results also offer empirical support to political cost and resource dependence theories. Within the SA context, apart from being part of King II and the 
JSE's listing rules, some of the stakeholder provisions, such as employment equity (EE) and black economic empowerment (BEE) are backed by statutory legislation. There are also occasional implicit threats from government (political cost) of its intentions to introduce more stringent laws if corporations do not voluntarily comply (Rossouw et al., 2002; West, 2006, 2009). This implies that listed corporations, and especially large companies, are more likely to voluntarily comply with the SCGI in order to minimise potential political costs.

Crucially, and of a particular relevance to basic materials and technology corporations, securing and renewing profitable government and mining contracts, for instance, are normally linked to satisfying BEE and EE targets (Murray, 2000; Malherbe and Segal, 2003). This means that compliance with the SCGI may be a major way by which firms can gain access to valuable resources that can facilitate growth and improve long-term financial performance. This seems to serve as a major additional motivation for corporations to voluntarily comply with the SCGI, and hence, appears to explain the positive association between the SCGI and $Q$.

Finally, the coefficients on the control variables in Columns 4 to 8 of Table 3 remain very similar to those reported in column 4 of Table 2 . The $F$-values in Table 3 consistently reject the null hypothesis that the coefficients on the SCGI are jointly equal to zero. The adjusted $R^{2}$ (between $6 \%$ and $41 \%$ ) suggests that the SCGI can explain variations in financial performance with or without the control variables.

\section{ROBUSTNESS ANALYSIS}

Our reported results so far ignore the existence of alternative financial performance proxies, CG weighting scheme and estimation technique. The positive link between our CGI and $Q$, for example, could be misleading. In this section, we examine how robust or sensitive our results are to the presence of alternative corporate financial performance proxies, CG weighting scheme and firm-level fixed-effects. 
First, we investigate how robust or sensitive our results are to two alternative financial performance proxies: total share returns (TSR - a market based measure) and return on assets (ROA - an accounting based proxy). Like Tobin's $Q$, these financial performance measures have been used widely within the CG literature (Gompers et al., 2003; Klapper and Love, 2004; Guest, 2009), and as such considered reliable. Table 4 reports regression results based on the alternative financial performance proxies, CG weights and estimation technique. Columns 3 and 4 contain OLS regression results of TSR on the CGI without and with the control variables, respectively. Columns 5 and 6 do similarly for the ROA, respectively. Our results show that the coefficients on the CGI in Columns 3 to 6 remain positive and statistically significant. This indicates that our results are robust whether a market (TSR) or an accounting (ROA) based measure of financial performance is used.

Insert Table 4 about here

Second, and similar to Beiner et al. (2006), we examine whether our results depend on the weighting of the 5 sections of our CGI. As the Appendix shows, our CGI contains 50 CG provisions based on 5 broad sections of King II. As has been explained in section 4, all 50 provisions forming the $C G I$ are equally weighted, but the number of provisions varies across the 5 sections. Thus, this simple equal weighting scheme results in different weights being assigned to each of the 5 sections: (1) board, directors, and ownership (54\%); accounting and auditing (12\%), risk management, internal audit and control (10\%); integrated sustainability reporting (18\%); and compliance and enforcement (6\%). To ascertain whether our results are robust or sensitive to equal weighting of the 5 sections, we construct an alternative $C G I$, defined as Weighted-CGI, in which each of the 5 sections is awarded a weight of $20 \%$. Consistent with the findings of Beiner et al. (2006), our results reported in Columns 7 and 8 of Table 4 indicate that the coefficients of the Weighted-CGI are positive and significant, suggesting that our results are robust to this alternative weighting scheme. 
Finally, corporations tend to differ in their opportunities and challenges that they encounter over time. This can result in a situation where CG and corporate financial performance are jointly determined by unobserved firm-specific variables (Henry, 2008; Guest, 2009), which simple OLS regressions may be unable to capture. Thus, given the panel nature of our data and in line with Henry (2008) and Guest (2009), we estimate a fixed-effects model to account for endogeneity problems that may arise from the existence of possible unobserved firm-level heterogeneity. We do this by re-estimating equation (1), in which we introduce 168 dummies to represent the 169 sampled corporations. Our fixed-effects results contained in Column 9 of Table 4 show that the coefficient on the CGI remains positive and significant, an indication that our results are robust to potential endogeneity problems that may arise from the presence of possible unobserved firm-level heterogeneity. Overall, the results from our robustness or sensitivity tests generally support our previous conclusion that better-governed SA corporations tend to be significantly associated with higher financial performance.

\section{SUMMARY AND CONCLUSIONS}

A number of papers have examined the relationship between a broad set of good corporate governance (CG) practices and corporate financial performance. Most of the studies have concentrated on the developed and emerging stock markets of America, Asia-Pacific and Europe. This leaves a conspicuous gap within the extant CG literature with respect to evidence regarding African stock markets. However, some African countries, and in particular, South Africa (SA) offer interesting research context. Unlike most African countries, SA has a matured corporate sector, deep equity culture, and strong regulatory and CG framework comparable to those of developed and other established emerging stock markets.

In this paper, we have attempted to fill this gap in the existing literature by investigating the association between a broad set of good CG practices and financial performance using a 
sample of 169 SA listed corporations from 2002 to 2007 and 50 CG provisions based on the 2002 King Report (King II). First, we find a significant and positive link between good CG practices (CGI) and Tobin's $Q(Q)$. This implies that better-governed SA corporations tend to be associated with higher financial performance. We show that our evidence is robust to endogeneity, accounting and market based firm value proxies, alternative $\mathrm{CG}$ index weighting scheme and unobserved firm-level heterogeneity.

Second, a distinctive feature of the SA CG framework is that it formally imposes substantial affirmative action and stakeholder CG provisions on listed corporations to comply with. This allows us to uniquely analyse the relationship between complying with stakeholder CG provisions (SCGI) and the financial performance of SA listed corporations. Our results show that SA corporations that comply better with the stakeholder $\mathrm{CG}$ provisions tend to be associated with higher financial performance. The results offer empirical support to political cost and resource dependence theories. Within the SA corporate context, compliance with stakeholder CG provisions appears to be a major way by which listed corporations can reduce political costs (like regulation, taxation, and nationalisation) and also gain access to resources (such as tax holidays and profitable government contracts) to facilitate growth and improve long-term financial performance.

Third, our results have important policy implications. The prior literature suggests that good CG framework is crucial to corporate success. Our results show that the investors reward corporations with better CG practices with higher financial performance. As an emerging market, good CG practices are particularly important as this may not only help reduce corporate failures, but may also help companies to attract foreign direct investments. This may facilitate faster economic growth and development in SA. In this respect, efforts by the Institute of Directors of SA, the King Committee, and the JSE at improving CG standards in SA companies is laudable. The significant positive relationship between the SCGI and financial performance implies that SA 
listed corporations may need to pay serious attention to complying with the affirmative action and stakeholder provisions and also in preparing the integrated sustainability report. Finally, whilst our findings are important, some caveats are in order. We use binary coding scheme which treats every CG mechanism as equally important. Whilst results based on our equally weighted $C G I$ and the alternatively weighted index are essentially similar, future studies may improve results by constructing weighted and un-weighted indices.

\section{REFERENCES}

ANDREASSON, S. (2010). Understanding corporate governance reforms in South Africa: Anglo American divergence, the King reports and hybridization. Business \& Society, Forthcoming. ARMSTRONG, P., SEGAL, N. and DAVIS, B. (2006). Corporate governance in South Africa', in Mallin, C. A. (eds), Handbook on International Corporate Governance, Cheltenham: Edward Elgar Publishing.

BAEK, J-S., KANG, J-K. and PARK, K. S. (2004). Corporate governance and firm value: evidence from the Korean financial Crisis. Journal of Financial Economics, 71: 265-313.

BARAKO, D. G., HANCOCK, P., and IZAN, H. Y. (2006). Factors influencing voluntary corporate disclosure by Kenyan companies, Corporate Governance: An International Review, 14(2): 107-125.

BARR, G., GERSON, J. and KANTO, B. (1995). Shareholders as agents and principals: The case for South Africa's corporate governance system, Journal of Applied Corporate Finance, 8(1): 18-31.

BARRIER, M. (1995). Pinciples not rules. Internal Auditor, 60: 68-73. 
BAUER, R., GUENSTER, N. and OTTEN, R. (2004). Empirical evidence on corporate governance in Europe: The effect on stock returns, firm value and performance. Journal of Asset Management, 5(2): 91-104.

BEATTIE, V., MCINNES, B. and FEARNLEY, S. (2004). A methodology for analysing and evaluating narratives in annual reports: A comprehensive descriptive profile and metrics for disclosure quality attributes. Accounting Forum, 28(3): 205-236.

BEBCHUK, L., COHEN, A. and FERRELL, A. (2009). What matters in corporate governance? Review of Financial Studies, 22(2): 783-827.

BEINER, S., DROBETZ, W., MARKUS, M. and ZIMMERMANN, H. (2006). An integrated framework of corporate governance and firm valuation. European Financial Management, 12(2): 249-283.

BHAGAT, S. and BOLTON, B. (2008). Corporate governance and firm performance', Journal of Corporate Finance, 14: 257-273.

BLACK, B., LOVE, I. and RACHINSKY, A. (2006a). Corporate governance indices and firm's market values: Time series evidence from Russia. Emerging Markets Review, 7(4): 361-379.

BLACK, B. S. (2001). The corporate governance behaviour and market value of Russian firms. Emerging Markets Review, 2(2): 89-108.

BLACK, B. S. and KHANNA, V. S. (2007). Can corporate governance reforms increase firms' market values? Event study evidence from India. Journal of Empirical Legal Studies, 4(4): 749796.

BLACK, B. S., JANG, H. and KIM, W. (2006b). Does corporate governance predict firm's market values? Evidence from Korea. Journal of Law, Economics and Organization, 22(2): 366-413.

BOTOSAN, C. A. (1997). Disclosure level and the cost of equity capital. Accounting Review, 72(3): 323-350.

BROWN, J. R., FAZZARI, S. M. and PETERSEN, B. C. (2009). Financing innovation and growth: Cash flow, external equity, and the 1990s R\&D boom. Journal of Finance, 64(1): 151185.

CHEN, K. C. W., ZHIHONG, C. and WEI, K. C. J. (2009). Legal protection of investors, corporate governance, and the equity cost of capital. Journal of Corporate Finance. 15(3): 273 388.

CHENG, S., EVANS, J. H. and NAGARAJAN, N. J. (2008). Board size and firm performance: Moderating effects of the market for corporate control. Review of Quantitative Financial Accounting, 31: 121-145.

CHEUNG, Y-L, CONNELLY, J. T., LIMPAPHAYOM, P. and ZHOU, L. (2007). Do investors really value corporate governance? Evidence from the Hong Kong market. Journal of International Financial Management and Accounting, 18(2): 86-122.

CHHAOCHHARIA, V. and GRINSTEIN, Y. (2007). Corporate governance and firm value: The impact of the 2002 governance rules. Journal of Finance, 62(4): 1789-1825.

CHHAOCHHARIA, V. and GRINSTEIN, Y. (2009). CEO compensation and board structure. Journal of Finance, 64(1): 231-261.

CLSA EMERGING MARKETS (2000). The tide's gone out: Who's swimming naked?, Hong Kong: Credit Lyonnais Securities Asia.

CORE, J. E. (2001). A review of the empirical disclosure literature: discussion. Journal of Accounting and Economics, 31(1-3): 441-456.

CREMERS, K. J. M. and NAIR, V. B. (2005). Governance mechanisms and equity prices. Journal of Finance, 60(6): 2859-2894.

DAVIDSON, S. (1998). Determinants of reputational signaling in South Africa. South African Journal of Economics, 62(1): 43-51. 
DAVIDSON, S. (1995). Director remuneration: Turnover, profit and agency. South African Journal of Economics, 63(2): 155-166.

DEANGELO, L. E. (1981). Auditor size and auditor quality. Journal of Accounting and Economics, 3: 181-199.

DEUTSCHE BANK (2002). Global corporate governance: valuing corporate governance in South Africa. New York: Deutsche Bank Securities Inc.

DROBETZ, W., SCHILLHOFER, A. and ZIMMERMANN, H. (2004). Corporate governance and expected stock returns: Evidence from Germany. European Financial Management, 10(2): 267-293.

DURNEV, A. and KIM, E. H (2005). To steal or not to steal: Firm attributes, legal environment, and valuation. Journal of Finance, 60(3): 1461-1493.

FORBES MAGAZINE (2011). Forbes global 2000 companies by market value. Available at: http://www.forbes.com/lists/2011/18/global-11, accessed on 27 June 2011.

GARAY, U. and GONZÁLEZ, M. (2008). Corporate governance and firm value: The case of Venezuela. Corporate Governance: An International Review, 16(3): 194-209.

GOMPERS, P., ISHII, J. and METRICK, A. (2003). Corporate governance and equity prices. Quarterly Journal of Economics, 118: 107-155.

GUEST, P. M. (2009). The impact of board size on firm performance: Evidence from the UK. European Journal of Finance, 15(4): 385-404.

GUJARATI, D. N. (2003). Basic Econometrics. New York: McGraw-Hill Companies.

HENRY, D. (2008). Corporate governance structure and the valuation of Australian firms: Is there value in ticking the boxes. Journal of Business Finance and Accounting, 35(7 \& 8): 912 942.

KING COMMITTEE (1994 \& 2002). King report on corporate governance for South Africa. Johannesburg: IOD South Africa.

JENSEN, M. C. (1986). Agency costs of free cash flow, corporate finance, and takeovers', American Economic Review, 76(2): 323-329.

JENSEN, M. C. and MECKLING, W. H. (1976). Theory of the firm: Managerial behaviour, agency costs and ownership structure. Journal of Financial Economics, 3: 305-360.

JERMIAS, J. (2007). The effects of corporate governance on the relationship between innovative efforts and performance. European Accounting Review, 16(4): 827-854.

KAKABADSE, A. and KORAC-KAKABADSE, N. (2002). Corporate governance in South Africa: Evaluating the King II report. Journal of Change Management, 2: 305-317.

KLAPPER, L. F. and LOVE, I. (2004). Corporate governance, investor protection, and performance in emerging markets. Journal of Corporate Finance, 10: 703-728.

KYEREBOAH-COLEMAN, A. (2007). Corporate governance and shareholder value maximization: An African perspective. African Development Review, 19(2): 350-367.

KYEREBOAH-COLEMAN, A. and BIEKPE, N. (2006). Corporate governance and financing choices of firms: A panel data analysis. South African Journal of Economics, 74(4): 670-681.

KYEREBOAH-COLEMAN, A., ADJASI, C. and ABOR, J. (2006). Corporate Governance and Performance of Ghanaian Listed Firms. Corporate Ownership and Control Journal, 4(2): 123132.

LA PORTA, R., LOPEZ-DE-SILANES, F., SHLEIFER, A. and VISHNY, R. (2002). Investor protection and corporate valuation. Journal of Finance, 57(3): 1147-1170.

LIPTON, M. and LORSCH, J. A (1992). Modest proposal for improved corporate governance. Business Lawyer, 48: 59-77.

LONDON STOCK EXCHANGE (LSE) (2007). Corporate governance update - CSR reporting is "excessive burden". Corporate Governance: An International Review, 15(1): 96-100. 
MALHERBE, S. and SEGAL, N. (2003). South Africa: After Apartheid', in Oman, C. P. (eds), Corporate governance in development, the experiences of Brazil, Chile, India, and South Africa. Washington: OECD.

MALLIN, C. A. (2006). Handbook on International Corporate Governance. Cheltenham: Edward Elgar Publishing.

MALLIN, C. A. (2007). Corporate governance, Oxford: Oxford University Press.

MANGENA, M. and CHAMISA, E. (2008). Corporate governance and incidences of listings suspension by the JSE Securities Exchange of South Africa: An empirical analysis.

International Journal of Accounting, 43: 28-44.

MOREY, M., GOTTESMAN, A., BAKER, E. and GODRIDGE, B. (2009). Does better corporate governance result in higher valuations in emerging markets? Another examination using a new data set. Journal of Banking and Finance, 33: 254-262.

MURRAY, G. (2000). Black empowerment in South Africa: "Patriotic capitalism" or a corporate black wash? Critical Sociology, 26(3): 183-2004.

NTIM, C. G. (2009). Internal corporate governance and firm financial performance: Evidence from South African listed firms. An unpublished PhD thesis, Glasgow: University of Glasgow.

NTIM, C.G., OPONG, K.K., DANBOLT, J. and THOMAS, D.A. (2011a). Voluntary Corporate Governance Disclosures by Post-Apartheid South African Corporations. Journal of Applied Accounting Research, Forthcoming.

NTIM, C. G., OPONG, K. K., and DANBOLT, J., (2011b). The Value Relevance of Shareholder versus Stakeholder Corporate Governance Disclosure Policy Reforms in South Africa. Corporate Governance: An International Review, Forthcoming.

NTIM, C. G. and OSEI, K. A. (2011). The Impact of Corporate Board Meetings on Corporate Performance in South Africa. African Review of Economics and Finance, forthcoming.

OKEAHALAM, C. C. (2004). Corporate governance and disclosure in Africa: Issues and challenges. Journal of Financial Regulation and Compliance, 12(4): 359-370.

PETERSEN, M. A. (2009). Estimating Standard Errors in Finance Panel Data Sets: Comparing Approaches. Review of Financial Studies 22: 435-80.

PFEFFER, J. (1973). Size, composition, and function of hospital boards of directors: A study of organization-environmental linkage. Administrative Science Quarterly, 18: 349-364.

ROSSOUW, G. J., WATT, A. V. and MALAN, D. P. (2002). Corporate governance in South Africa. Journal of Business Ethics, 37: 289-302.

SANDA, A., MIKAILU, A. S. and GARBA, T. (2010). Corporate Governance Mechanisms and Firm Financial Performance in Nigeria. Afro-Asian Journal of Finance and Accounting 2: 2239.

SPISTO, M. (2005). Unitary or two-tiered board for the new South Africa? International Review of Business Research Papers, 1(2): 84-99.

SUNDAY, K. O. (2008). Corporate Governance and Firm Performance: The Case of Nigerian Listed Firms. European Journal of Economics, Finance and Administrative Sciences, 14: 16-28.

WATTS, R. L. and ZIMMERMAN, J. L. (1978). Towards a positive theory of the determination of accounting standards. Accounting Review, 53(1): 112-134.

WEIR C., LAING, D. and MCKNIGHT, P. J. (2002). Internal and external governance mechanisms: Their impact on the performance of large UK public companies. Journal of Business Finance and Accounting, 29(5): 579-611.

WEST, A. (2006). Theorising South Africa's corporate governance. Journal of Business Ethics, 68: 433-448.

WEST, A. (2009). The ethics of corporate governance: A South African perspective',International Journal of Law and Management, 51(1): 10-16. 
WORLD FEDERATION OF EXCHANGES (WFE) (2011). Available

at:http://www.worldexchanges.org/WFE/home.asp?menu=436\&document=4822/ accessed on 10 May 2011).

YERMACK, D. (1996). Higher market valuation of companies with a small board of directors', Journal of Financial Economics, 40: 185-211.

YOUNG, C-S., TSAI, L-C. and HSIEH, P.G. (2008). Voluntary appointment of independent directors in Taiwan: motives and consequences', Journal of Business Finance and Accounting, 35(9 \& 10): 1103-1137.

Appendix: Full List of the SA Corporate Governance Index Provisions Based on King II

Section 1: Board, directors and ownership

1. Whether the roles of chairperson and CEO/MD are split.

2. Whether the chairperson of the board is independent non-executive directors.

3. Whether the board is composed by a majority of non-executive directors (NEDs).

4. Whether the board meets at least 4 times in a year.

5. Whether individual directors' meetings record is disclosed.

6. Whether directors are clearly classified into executive, NED, and independent.

7. Whether chairperson's performance and effectiveness is evaluated and disclosed.

8. Whether CEO/MD's performance and effectiveness is appraised and disclosed.

9. Whether the board's performance and effectiveness is evaluated and disclosed. 
10. Whether the board subcommittees' performance and effectiveness is evaluated.

11. Whether directors' biography, experience and responsibilities are disclosed.

12. Whether a policy that prohibits directors, officers and employees (insider) share dealings around the release of price sensitive information is disclosed.

13. The existence of the office of company secretary.

14. Whether a nomination committee has been established.

15. Whether the nomination committee consists of a majority independent NEDs.

16. Whether the chairperson of the nomination committee is an independent NED.

17. Whether the membership of the nomination committee is disclosed.

18. Whether the nomination committee's members' meetings attendance record is disclosed.

19. Whether a remuneration committee has been established.

20. Whether the remuneration committee is constituted entirely by independent NEDs.

21. Whether the chairperson of the remuneration committee is an independent NEDs.

22. Whether the membership of the remuneration committee is disclosed.

23. Whether the remuneration committee's members' meetings attendance record is disclosed.

24. Whether directors' remuneration, interests, and share options are disclosed.

25 . Whether director remuneration philosophy and procedure is disclosed.

26. Whether directors' have access to free independent professional legal advice.

27. Whether share ownership by directors and officers (internal share ownership) is less than $50 \%$ of the total company shareholdings.

\section{Section 2: Accounting and auditing}

28. Whether an audit committee has been established.

29. Whether the audit committee is constituted by at least 2 independent NEDs with significant professional financial training and experience.

30. Whether the chairperson of the audit committee is an independent NED.

31 . Whether the membership of the audit committee is disclosed.

32. Whether the audit committee's members' meetings attendance record is disclosed.

33. Whether a board statement on the going-concern status of the firm is disclosed.

\section{Section 3: Risk management, internal audit and control}

34. Whether a risk management committee has been established.

35. Whether the risk committee's members' meetings attendance record is disclosed.

36. Whether a narrative on both actual and potential future systematic and non-systematic risks is disclosed.

37. Whether a narrative (policy) on existing internal control systems (including internal audit) is disclosed.

38. Whether narrative (policy) on how current and future assessed company risks will be managed is disclosed.

Section 4: Integrated sustainability reporting (non-financial information)

39. Whether a narrative (policy) on how a firm is complying with and implementing the broad-based black economic empowerment and empowerment of women laws is disclosed.

40. Whether a narrative (policy) on how a firm is complying with and implementing employment equity laws in terms of gender, age, ethnicity and disabilities is disclosed. 
41. Whether a narrative (policy) on how a firm is addressing the threat posed by HIV/AIDS pandemic in South Africa is disclosed.

42. Whether a narrative (policy) on measures taken by a firm to address occupational health and safety of its employees is disclosed.

43. Whether a narrative (policy) on how a firm is complying with and implementing rules and regulations on the environment is disclosed.

44. Whether a narrative (policy) on the existence of a code of ethics is disclosed.

45. Whether a firm's board is formed by at least 1 white and 1 non-white (board diversity on the basis of ethnicity) person.

46. Whether a firm's board is formed by at least 1 male and 1 female (board diversity on the basis of gender) person.

47. Whether a narrative (policy) on community support and other corporate social investments or responsibilities is disclosed.

Section 5: Encouraging a culture of voluntary compliance and enforcement

48. Whether a positive statement on the compliance or non-compliance with the corporate governance provisions of King II is disclosed.

49. Whether a narrative (policy) on how a firm is contributing towards the development of financial journalism is disclosed.

50. Whether a narrative (policy) on what a firm is doing to encourage shareholder activism, like having investor relations department and proxy voting is disclosed.

Table 1. Descriptive statistics of all continuous variables for all (845) firm years

Variable

Q

ROA

TSR

CGI

SCGI

GROWTH

CAPEX
Mean

Median

Std. dev

Maximum

Minimum

1.55

.09

.39

.61

.69

.20

.15

Financial Performance Variables

\subsection{3}

.11

.30
.91

.20

1.02

Corporate Governance Variables
.15

$-2.40$

$-.98$

.06

.00
1.00

22.36

9.90
$-1.00$

.00 


$\begin{array}{lrrrrr}\text { GEAR } & .67 & .15 & 5.91 & 15.53 & .00 \\ \text { LNTA } & 5.95 & 5.97 & .91 & 8.01 & 3.25 \\ \text { CGCOM } & .32 & .00 & .47 & 1.00 & .00 \\ \text { BIG4 } & .73 & 1.00 & .44 & 1.00 & .00 \\ \text { CROSLIST } & .22 & .00 & .41 & 1.00 & .00\end{array}$

Notes: Variables are defined as follows: Tobin's Q (Q), measured as the ratio of total assets minus book value of equity plus market value of equity to total assets. Return on assets (ROA), calculated as the ratio of operating profit to total assets. Total share returns (TSR), defined as the total share returns made up of share price and dividends. South African corporate governance index (CGI), refers to a corporate governance (CG) index containing 50 provisions in King II that takes a value of 1 if each of the $50 \mathrm{CG}$ provisions is disclosed, 0 otherwise; scaled to a value between $0 \%$ and $100 \%$. Social CGI (SCGI), which is a sub-index of the CGI containing 9 SA context specific affirmative action and stakeholder CG provisions that form the CGI. Sales growth (GROWTH), measured as the ratio of the current year's sales minus last year's sales to last year's sales. Capital expenditure (CAPEX), calculated as the ratio of total capital expenditure to total assets. Gearing (GEAR), estimated as the ratio of total debt to market value of equity. Firm size (LNTA), calculated as the natural log of total assets. CG committee (CGCOM), measured as a dummy variable that takes that value of 1 if a firm has set up a CG committee, 0 otherwise. Audit firm size (BIG4), measured as a dummy variable that takes the value of 1, if a firm is audited by a big four audit firm (PricewaterhouseCoopers, Deloitte \& Touche, Ernst \& Young, and KPMG), 0 otherwise. Cross-listing (CROSLIST), defined as a dummy variable that takes the value of 1 , if a firm is cross-listed on foreign stock markets, 0 otherwise. 
Table 2. OLS regression results of $Q$ on the CGI and control variables

\begin{tabular}{|c|c|c|c|c|c|c|c|}
\hline & $\begin{array}{l}\text { Exp. } \\
\text { Sign }\end{array}$ & All firm years & All firm years & 2004 & 2005 & 2006 & 2007 \\
\hline Adjusted $R^{2}$ & & .061 & .411 & .316 & .243 & .218 & .258 \\
\hline Standard error & & .658 & .434 & .502 & .524 & .635 & .496 \\
\hline Durbin-Watson & & 1.985 & 2.168 & 2.089 & 2.142 & 2.112 & 2.185 \\
\hline F-value & & $11.004(.000)^{* * *}$ & $14.545(.000)^{* * *}$ & $6.438(.000)^{* * * *}$ & $3.504(.000)^{* * *}$ & $3.486(.000)^{* * *}$ & $4.978(.000)^{* * *}$ \\
\hline Sample size $(N)$ & & 845 & 845 & 169 & 169 & 169 & 169 \\
\hline Constant & & $.864(.000)^{* * * *}$ & $.549(.000)^{* * * *}$ & $.442(.000)^{* * * *}$ & $.386(.000)^{* * * *}$ & $.648(.000)^{* * *}$ & $.524(.000)^{* * * *}$ \\
\hline CGI & + & $.006(.000)^{* * *}$ & $.003(.005)^{* * *}$ & $.002(.028)^{* *}$ & $.004(.000)^{* * *}$ & $.007(.000)^{* * *}$ & $.008(.000)^{* * *}$ \\
\hline BIG4 & + & - & $.062(.156)$ & $.164(.182)$ & $.152(.423)$ & $.085(.327)$ & $.132(.458)$ \\
\hline CAPEX & $-/+$ & - & $.000(.757)$ & $.012(.426)$ & $.008(.672)$ & $.004(.586)$ & $.038(.085)^{*}$ \\
\hline CROSLIST & + & - & $.100(.038)^{* *}$ & $.214(.004)^{* * *}$ & $.164(.048)^{* *}$ & $.143(.008)^{* * *}$ & $.194(.000)^{* * *}$ \\
\hline LNTA & $-/+$ & - & $-.093(.002)^{* * *}$ & $-.046(.045)^{* *}$ & $-.082(.050)^{* *}$ & $-.110(.016)^{* *}$ & $-.041(.084)^{*}$ \\
\hline GEAR & $-/+$ & - & $.000(.744)$ & $.001(.539)$ & $.002(.294)$ & $.000(.149)$ & $.001(.193)$ \\
\hline GROWTH & $-/+$ & - & $.001(.008)^{* * * *}$ & $.036(.026)^{* *}$ & $.005(.012)^{* *}$ & $.009(.098)^{*}$ & $.007(.086)^{*}$ \\
\hline Basic materials & & - & $.046(.430)$ & $.237(.241)$ & $.126(.348)$ & $.188(.284)$ & $.259(.391)$ \\
\hline Consumer services & & - & $.212(.000)^{* * * *}$ & $.358(.026)^{* *}$ & $.435(.014)^{* *}$ & $.546(.028)^{* *}$ & $.651(.032)^{* *}$ \\
\hline Industrials & & - & $.042(.452)$ & $.055(.360)$ & $.087(.165)$ & $.129(.278)$ & $.148(.561)$ \\
\hline Technology & & - & $.059(.366)$ & $.152(.324)$ & $.240(.386)$ & $.283(.426)$ & $.384(.263)$ \\
\hline Year 2004 & & - & $.193(.000)^{* * *}$ & - & - & - & - \\
\hline Year 2005 & & - & $.224(.000)^{* * *}$ & - & - & - & - \\
\hline Year 2006 & & - & $.268(.000)^{* * *}$ & - & - & - & - \\
\hline Year 2007 & & - & $.296(.000)^{* * *}$ & - & - & - & - \\
\hline
\end{tabular}

Notes: Coefficients are in front of parenthesis. $* * *, * *$ and $*$ indicate that p-value is significant at the $1 \%, 5 \%$ and $10 \%$ level, respectively. The consumer goods industry and yea 2003 are captured by the constant term in the pooled analysis. Following Petersen (2009), coefficients are estimated by using the robust clustered standard errors technique. Variables are defined as follows: Tobin's Q $(Q)$, South African corporate governance index (CGI), audit firm size (BIG4), capital expenditure (CAPEX), cross-listing (CROSLIST), firm size $(L N T A)$, gearing $(G E A R)$ and growth $(G R O W T H)$. Table 1 fully defines all the variables used. 
Table 3. OLS regression results of $Q$ on the SCGI and control variables

\begin{tabular}{|c|c|c|c|c|c|c|c|}
\hline & $\begin{array}{l}\text { Exp. } \\
\text { Sign }\end{array}$ & All Firm Years & All Firm Years & 2004 & 2005 & 2006 & 2007 \\
\hline Adjusted $R^{2}$ & & .059 & .408 & .232 & .165 & .138 & .248 \\
\hline Standard error & & .676 & .436 & .568 & .593 & .625 & .629 \\
\hline Durbin-Watson & & 1.963 & 2.125 & 2.042 & 2.014 & 2.002 & 2.103 \\
\hline F-value & & $10.248(.000)^{\text {**** }}$ & $12.820(.000)^{* * *}$ & $5.602(.000)^{* * * *}$ & $3.938(.000)^{* * * *}$ & $4.385(.000)^{* * *}$ & $4.850(.000)^{* * *}$ \\
\hline Sample size $(N)$ & & 845 & 845 & 169 & 169 & 169 & 169 \\
\hline Constant & & $.785(.000)^{* * * *}$ & $.472(.002)^{* * * *}$ & $.367(.089)^{*}$ & $.438(.029)^{* *}$ & $.325(.092)^{*}$ & $.434(.000)^{* * *}$ \\
\hline SCGI & $-/+$ & $.002(.000)^{* * *}$ & $.001(.046)^{* *}$ & $.004(.062)^{*}$ & $.001(.095)^{*}$ & $.003(.081)^{*}$ & $.003(.000)^{* * *}$ \\
\hline BIG4 & + & - & $.080(.066)^{*}$ & $.384(.254)$ & $.114(.326)$ & $.045(.468)$ & $.205(.514)$ \\
\hline CAPEX & $-/+$ & - & $.000(.648)$ & $.000(.692)$ & $.008(.412)$ & $.000(.457)$ & $.051(.097)^{*}$ \\
\hline CROSLIST & + & - & $.108(.025)^{* *}$ & $.139(.094)^{*}$ & $.014(.086)^{*}$ & $.158(.046)^{* *}$ & $.186(.000)^{* * *}$ \\
\hline LNTA & $-/+$ & - & $-.061(.028)^{* *}$ & $-.002(.085)^{*}$ & $-.098(.070)^{*}$ & $-.102(.028)^{* *}$ & $-.075(.093)^{*}$ \\
\hline GEAR & $-/+$ & - & $.000(.587)$ & $.000(.631)$ & $.000(.456)$ & $.000(.562)$ & $.000(.630)$ \\
\hline GROWTH & $-/+$ & - & $.001(.024)^{* *}$ & $.000(.038)^{* *}$ & $.048(.065)^{*}$ & $.001(.088)^{*}$ & $.009(.076)^{*}$ \\
\hline Basic Materials & & - & $.035(.547)$ & $.429(.363)$ & $.405(.420)$ & $.628(.431)$ & $.440(.530)$ \\
\hline Consumer Services & & - & $.221(.000)^{* * * *}$ & $.208(.042)^{* *}$ & $.532(.045)^{* *}$ & $.409(.049)^{* *}$ & $.568(.069)^{*}$ \\
\hline Industrials & & - & $.056(.318)$ & $.063(.428)$ & $.061(.478)$ & $.321(.630)$ & $.608(.524)$ \\
\hline Technology & & - & $.068(.301)$ & $.090(.507)$ & $.328(.612)$ & $.417(.496)$ & $.490(.515)$ \\
\hline Year 2004 & & - & $.212(.008)^{* * * *}$ & - & - & - & - \\
\hline Year 2005 & & - & $.261(.000)^{* * *}$ & - & - & - & - \\
\hline Year 2006 & & - & $.283(.000)^{* * *}$ & - & - & - & - \\
\hline Year 2007 & & - & $.300(.000)^{* * *}$ & - & - & - & - \\
\hline
\end{tabular}

Notes: Coefficients are in front of parenthesis. $*_{* *}^{* * *}$ and $*$ indicate that p-value is significant at the $1 \%, 5 \%$ and $10 \%$ level, respectively. The consumer goods industry and year 2003 are captured by the constant term in the pooled analysis. Following Petersen (2009), coefficients are estimated by using the robust clustered standard errors technique. Variables are defined as follows: Tobin's Q $(Q)$, Social-CGI (SCGI), audit firm size (BIG4), capital expenditure (CAPEX), cross-listing (CROSLIST), firm size (LNTA), gearing (GEAR) and growth $(G R O W T H)$. Table 1 fully defines all the variables used. 
Table 4. Regression results based on alternative financial performance proxies, weighted CG index and fixed-effects estimation

\begin{tabular}{|c|c|c|c|c|c|c|c|c|}
\hline \multirow{7}{*}{$\begin{array}{l}\text { Adjusted } R^{2} \\
\text { Standard error } \\
\text { Durbin-Watson } \\
\text { F-value } \\
\text { Sample size }(N)\end{array}$} & \multirow[b]{2}{*}{$\begin{array}{l}\text { Exp. } \\
\text { Sign }\end{array}$} & \multicolumn{4}{|c|}{ Alternative Financial Performance proxies } & \multirow{2}{*}{\multicolumn{2}{|c|}{$\begin{array}{c}\text { Alternatively Weighted } C G I \\
\text { Tobin's } Q \\
(Q)\end{array}$}} & \multirow{2}{*}{$\begin{array}{c}\text { Fixed-effects } \\
\text { Tobin's Q } \\
(Q) \\
\end{array}$} \\
\hline & & \multicolumn{2}{|c|}{$\begin{array}{c}\text { Total Share Returns } \\
(T S R)\end{array}$} & \multicolumn{2}{|c|}{$\begin{array}{c}\text { Return on Assets } \\
(\text { ROA })\end{array}$} & & & \\
\hline & & .036 & .198 & .048 & .315 & .025 & .138 & .590 \\
\hline & & .474 & .433 & .113 & .108 & .654 & .436 & .389 \\
\hline & & 1.518 & 2.150 & 1.935 & 2.104 & 1.428 & 2.112 & 2.243 \\
\hline & & $3.314(.000)^{* * *}$ & $3.909(.000)^{* * *}$ & $4.124(.000)^{* * *}$ & $8.856(.000)^{* * *}$ & $1.802(.096)^{*}$ & $2.678(.086)^{*}$ & $9.306(.000)^{* * *}$ \\
\hline & & 845 & 845 & 845 & 845 & 845 & 845 & 845 \\
\hline Constant & & $-.010(.871)$ & $.204(.165)$ & $-.022(.127)$ & $.035(.218)$ & $.028(.264)$ & $.424(.627)$ & $.725(.019)^{* * *}$ \\
\hline CGI & + & $.005(.000)^{* * *}$ & $.004(.007)^{* * *}$ & $.006(.000)^{* * *}$ & $.004(.009)^{* *}$ & - & - & $.004(.006)^{* * *}$ \\
\hline Weighted-CGI & + & - & - & - & - & $.004(.010)^{* * *}$ & $.003(.008)^{* *}$ & - \\
\hline BIG4 & + & - & $-.024(.589)$ & - & $.009(.281)$ & - & $.082(.059)^{*}$ & $.058(.656)$ \\
\hline CAPEX & + & - & $-.002(.100)^{*}$ & - & $-.000(.699)$ & - & $.000(.661)$ & $-.002(.437)$ \\
\hline CROSLIST & $-/+$ & - & $.004(.935)$ & - & $.007(.065)^{*}$ & - & $.112(.020)^{* *}$ & $-.010(.917)$ \\
\hline LNTA & + & - & $-.046(.125)$ & - & $-.007(.058)^{*}$ & - & $-.051(.036)^{* *}$ & $-.062(.098)^{*}$ \\
\hline GEAR & $-/+$ & - & $.000(.350)$ & - & $-.015(.009)^{* * *}$ & - & $.000(.529)$ & $.001(.255)$ \\
\hline GROWTH & $-/+$ & - & $.003(.000)^{* * * *}$ & - & $.000(.341)$ & - & $.000(.218)$ & $.001(.091)^{*}$ \\
\hline Basic materials & + & - & $-.006(.916)$ & - & $-.022(.044)^{* *}$ & - & $.039(.505)$ & $.073(.103)$ \\
\hline Consumer services & & - & $.086(.131)$ & - & $.008(.495)$ & - & $.229(.062)^{*}$ & $.324(.083)^{*}$ \\
\hline Industrials & & - & $.138(.013)^{* *}$ & - & $.000(.943)$ & - & $.063(.254)$ & $.216(.385)$ \\
\hline Technology & & - & $-.107(.100)^{*}$ & - & $.008(.505)$ & - & $.077(.237)$ & $.284(.529)$ \\
\hline Year 2004 & & - & $.118(.015)^{* *}$ & - & $-.013(.160)$ & - & $.098(.054)^{*}$ & $.209(.000)^{* * *}$ \\
\hline Year 2005 & & - & $.204(.000)^{* * *}$ & - & $.006(.563)$ & - & $.306(.000)^{* * *}$ & $.388(.000)^{* * *}$ \\
\hline Year 2006 & & - & $.348(.000)^{* * *}$ & - & $.003(.799)$ & - & $.268(.000)^{* * *}$ & $.456(.000)^{* * *}$ \\
\hline Year 2007 & & & $.495(.000)^{* * *}$ & - & - & - & - & - \\
\hline
\end{tabular}

Notes: Coefficients are in front of parenthesis. $* * *, * *$ and $*$ indicate that p-value is significant at the $1 \%, 5 \%$ and $10 \%$ level, respectively. The consumer goods industry and year 2003 are captured by the constant term in the pooled analysis. Following Petersen (2009), coefficients are estimated by using the robust clustered standard errors technique. Variables are defined as follows: Tobin's Q $(Q)$, South African corporate governance index $(C G I)$, Weighted CGI (Weighted-CGI), audit firm size (BIG4), capital expenditure (CAPEX), crosslisting (CROSLIST), firm size (LNTA), gearing (GEAR) and growth (GROWTH). Table 1 fully defines all the variables used. 